Article

\title{
Sustainability: Living within One's Own Ecological Means
}

\section{Lee Liu}

Department of Geography and Interdisciplinary Studies, University of Central Missouri, Wood 8, Warrensburg, MO 64093, USA; E-Mail: laliu@ucmo.edu; Tel.: +1-660-543-8789; Fax: +1-660-543-8148.

Received: 26 October 2009 / Accepted: 16 December 2009 / Published: 21 December 2009

\begin{abstract}
This paper provides a critical review of sustainability, including its definitions, dimensions, measurements, and practices, as well as approaches to achieve sustainability. It raises questions about conventional definitions and argues for taking into account the geographic dimension of sustainability for better understanding of the regional differences in sustainability and transition to sustainability. The paper proposes that sustainability should be defined as "living within one's own ecological means." This definition pays attention to regional disparities in biocapacity and ecological footprint. It realizes that not all people's present and future needs may be met in all regions of the world.
\end{abstract}

Keywords: sustainability definition; sustainability transition; sustainability science; ecological footprint; Environmental Kuznets Curve; geography; weak sustainability; strong sustainability

\section{Introduction}

An enormous increase in publications on sustainability has accompanied imperative concerns over global environmental degradation and climate change [1]. Focusing on understanding the complex dynamics of human-environment interactions, the resulting field of sustainability science has been expanding at an accelerated pace and in multiple directions [2-6]. The meaning of sustainability has been broadening and deepening. In introducing Sustainability, Curran outlines various, inter-related concepts and basic practices and approaches that are being used in the name of sustainability, including: traditional end-of-pipe control strategies, life cycle, environmental sustainability, urban sustainability, industrial ecology, business sustainability, sustainable supply chain systems, 
sustainability indicators and metrics, green chemistry and green engineering, design for the environment, sustainable buildings, eco-tourism, and renewable and sustainable energy and fuels [7]. In addition, Rosen points out that despite the growing interest in and need for sustainability, new developments and advances are required before sustainability can be more widely incorporated into the activities of industry, government and society [8]. This paper gives an additional critical review of sustainability definitions, dimensions, indicators, practices, as well as approaches to achieve sustainability. It particularly argues for the importance of the geographic dimension of sustainability for better understanding sustainability definition and the transition to sustainability.

\section{A Review of the Definition of Sustainability}

The sustainability literature is filled with numerous conflicting definitions of sustainability [7-22]. The widely used first definition of sustainability came from the United Nations' World Commission on Environment and Development (Brundtland Commission) introduced the far-reaching implications of the term, "sustainable," in their widely cited report, Our Common Future [23]: "Humanity has the ability to make development sustainable - to ensure that it meets the needs of the present without compromising the ability of future generations to meet their needs." That definition is so vague that it would be impossible to quantify or implement, according to Barrett and Odum [24]. Curran states that sustainability is a destination that we aspire to reach with the selection of the sustainable pathways that we choose as we proceed along the journey [7].

As a variety of academic disciplines study sustainability, different researchers emphasize different aspects of sustainability. These include ecological sustainability [25], economic and social sustainability [26-28], land restorativeness, environmental soundness, economic viability and social acceptability [29], sustainability of all agricultural resources [20,30], and sustainability from a political economy and political ecology perspective [31-33]. Rosen applies a pragmatic approach to demonstrate that several crucial factors need to be addressed appropriately to achieve energy sustainability, and thereby allow it to contribute to sustainable development [34].

Many concepts of sustainable agriculture have emerged. They include fertility agriculture, organic agriculture, biodynamic agriculture, biological agriculture, integrated agriculture, agro-ecological engineering, bio-ecological agriculture, ecological agriculture, scientific ecological agriculture, regenerative agriculture, and conservational agriculture [20]. In Brazil, sustainable agriculture refers to the type of the farming that maintains both the quality and nutrients of the soil, permitting long-term use of each lot of land, and the environmental and ecological integrity of the soil, water, and land systems in the area while providing sufficient income to farmers through intercropping [35]. China uses a broader definition of sustainable agriculture [20] that gives priority to food production and security, while ensuring a balance between self-sufficiency and production for markets, and promoting rural employment and income generation to alleviate poverty, and natural resource management and environmental protection [36]. Though the term is newly developed [37,38], different forms of sustainable agriculture have been practiced in China for thousands of years to increase food production and fight ecosystem degradation [20,32,38]. It has been promoted by the Chinese central government and research institutions since the mid-1980s [20,32,39]. 
In developed countries, sustainable programs are cost-effective and make use of local materials and skills whereas conservation programs are not economically restricted [40]. In many developing countries, however, conservation and sustainable agriculture are one and the same. Conservation means to conserve the land to increase productivity and income, prevent degradation, and achieve sustainable development. It uses local materials and skills to be cost-effective.

\section{Problems with the Definition of Sustainability}

The Brundtland definition of sustainability [23] may be regarded as a compromise between the increasing demands for both environmental protection and economic development. "Development" originally meant economic development but later on expanded to include social and cultural development. Environmental protection and economic development were often seen as contradictory because economic development, especially industrialization, degrades the environment and depletes natural resources while environmental protection takes money away from investment in and increases the cost of economic development.

The notion of sustainable development supports economic growth with reduced impact on the environment. It also assumes that the Earth is able to provide enough resources for humankind to meet both present and future needs. It would certainly be wonderful if that is the case. However, there is not enough evidence to support that assumption. That assumption is questionable as the Earth's resources are finite and are being depleted and degraded. According to Global Footprint Network, it would now take nearly one and a half Earths to generate all the resources humanity consumes and absorb all our $\mathrm{CO}_{2}$ emissions [41]. More importantly, distribution of resources has always been and will always be unequal between and within countries. What shall we do if we do not have enough resources to meet both present and future needs? Which needs do we compromise? What shall we do if we do not have resources to meet either present or future needs? Which needs do we sacrifice?

In addition, the terms used in the Brundtland definition are open to interpretation and will depend on the particular context under consideration [42]. "Needs" may simply mean basic needs such as food and shelter for some but much more than that for the other. Clark and Kates point out that there is an implicit hierarchy of needs that favors children and people in disasters and that favors feeding and nurturing first, followed by education, housing, and employment [43]. People in more developed countries may regard cars, air conditioning, and air travel as their needs, which are not available to majority people in the poorest countries. The United States government certainly justifies its defense spending as its needs. North Korea's government may include nuclear weapons in its needs even though its people do not have enough to eat. China spent tens of billions of dollars on its military parade in Beijing to celebrate the 60th anniversary of the People's Republic. The government certainly thought they needed that celebration badly when they argued that they did it as cheaply as possible [44]. It is also difficult to determine if the "needs" are met and at what level. Does 100 percent of the "needs" have to be met? Shall we measure by a country's or region's average? Should we meet everyone's needs or only those of the majority population? Given high levels of income inequality, the richest countries still have poor people whose basic needs are not met, while some poor countries have billionaires. The billionaires may argue that their country is still poor and 
needs more economic growth. However, the economic growth is often achieved at the expense of the poor people and the environment.

\section{Dimensions of Sustainability}

In addition to environmental needs and material needs that may be fulfilled through economic development, humans also need social development to improve social justice, equality, and security. Thus, sustainability has been illustrated as having three overlapping dimensions: the simultaneous pursuit of economic prosperity, environmental quality, and social equity, also known as the "three pillars" of sustainability (Figure 1a) [45,46]. This model gives better attention to environmental concerns than the conventional wisdom that economic development is the key in nature-society relations.

The model was later criticized for not adequately showing that societies and economies are fundamentally reliant on the natural world. Porritt argues that the economy is a subsystem of human society which is a subsystem of the totality of life on Earth (the biosphere) and no subsystem can expand beyond the capacity of the total system of which it is a part (Figure 1b) [47,48]. The concept of living within environmental constraints was discussed by Daly and Cobb who define sustainable development as improving the quality of human life while living within the carrying capacity of supporting eco-systems [49].

Other dimensions of sustainability have been proposed. A widely accepted one is cultural sustainability. The Universal Declaration on Cultural Diversity [50] further elaborates the concept by stating that cultural diversity is as necessary for humankind as biodiversity is for nature; it becomes one of the roots of development understood not simply in terms of economic growth, but also as a means to achieve a more satisfactory intellectual, emotional, moral and spiritual existence. Cultural sustainability is promoted by universities [51,52] and international organizations [53].

Scholars have also proposed that sustainability should include technical, legal political [54], and philosophical dimensions [55-57]. Skowroński states that the initiation of a civilization founded upon sustainable development would seem to be the best option for further civilizational progress [58]. Pataki argues for ecological modernization [59]. The Chinese government has been promoting ecological civilization $[60,61]$.

Figure 1. (a) Diagrams showing the three overlapping components of sustainability and (b) economy and society as being constrained by environmental limits.
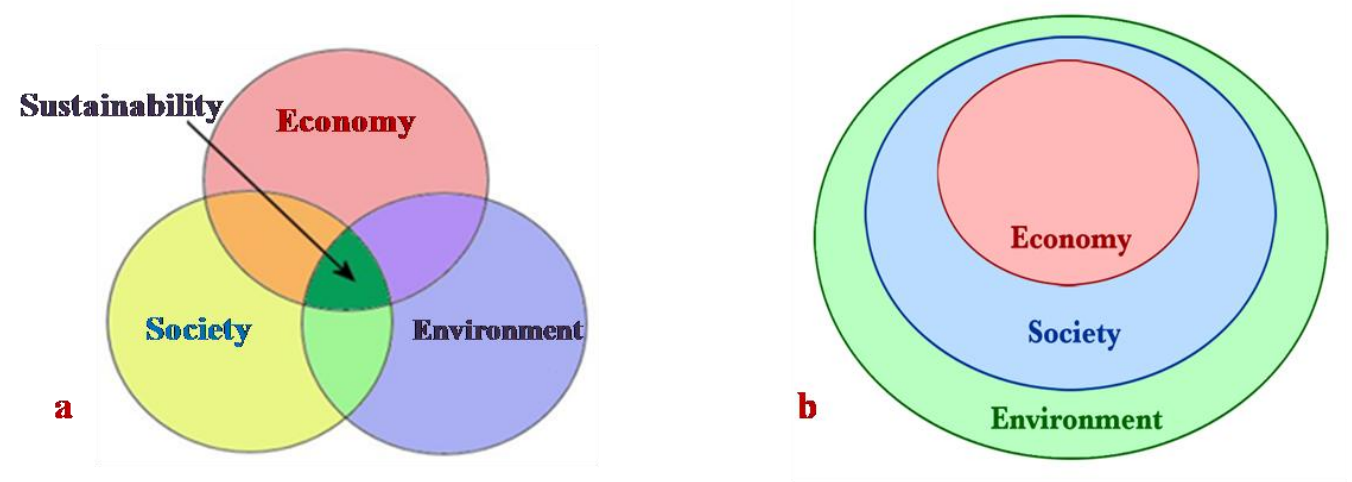


\section{Sustainability Science}

Another new development is the notion of sustainability science. Kates et al. developed the notion of sustainability science to foster a problem orientated and interdisciplinary form of knowledge production for understanding the complex dynamics of human-environmental interactions [62]. Sustainability science focuses on the dynamic interactions between nature and society. Kates and Parris believe that it is the responsibility of sustainability science to map the broad, inclusive, and contradictory currents that humankind will need to navigate toward a just and sustainable future [3]. The Sustainability Science Program at Harvard University [63] seeks to: "Advance basic understanding of the dynamics of human-environment systems; to facilitate the design, implementation, and evaluation of practical interventions that promote sustainability in particular places and contexts; and to improve linkages between relevant research and innovation communities on the one hand, and relevant policy and management communities on the other."

\section{Indicators of Sustainability}

There are no globally agreeable indicators of sustainability, though a few such indicators have been proposed. The Environmental Performance Index (EPI) is one of them. As a new global ranking of environmental performance, the 2008 EPI was produced by a team of environmental experts at Yale and Columbia Universities led by Daniel Esty [64]. The EPI report ranks 149 countries on 25 indicators tracked across six established policy categories: Environmental Health, Air Pollution, Water Resources, Biodiversity and Habitat, Productive Natural Resources, and Climate Change. The EPI identifies broadly-accepted targets for environmental performance and measures how close each country comes to these goals. Its Executive Summary states many of the qualities of the EPI:

As a quantitative gauge of pollution control and natural resource management results, the Index provides a powerful tool for improving policymaking and shifting environmental decision-making onto firmer analytic foundations.

The 2008 EPI focuses on two overarching environmental objectives: reducing environmental stresses to human health and promoting ecosystem vitality and sound natural resource management. The two objectives are gauged using 25 performance indicators tracked in six well-established policy categories.

The 2008 EPI brings a data-driven, fact-based empirical approach to environmental protection and global sustainability. .... seeks to draw attention to the value of accurate data and sound analysis as the basis for environmental policymaking.... provides both an empirical foundation for policy analysis and a context for evaluating performance, facilitating cross-country comparisons both globally and within relevant peer groups such as geography or economy.... provides a powerful tool for steering environmental investments, refining policy choices, optimizing the impact of limited financial resources, and understanding the determinants of policy results.

The 2008 EPI apparently gives human health associated with pollution and thus economic factors too much weight in the calculation of the EPI, according to my earlier research [65]. Thus it is not an 
accurate indicator of environmental performance or sustainability. Ecological Footprint (EF) has also been used as an indicator for environmental sustainability. According to the Global Footprint Network, $\mathrm{EF}$ is a measure of how much biologically productive land and water an individual, population or activity requires to produce all the resources it consumes and to absorb the waste it generates using prevailing technology and resource management practices [66]. The EF is usually measured in global hectares. Because trade is global, an individual or country's Footprint includes land or sea from all over the world. EF is often referred to in short form as Footprint (not footprint). When used in EF studies, Carbon Footprint is synonymous with demand on $\mathrm{CO} 2$ area. Holden and Linnerud argue for using ecological footprint as the indicator for long-term ecological sustainability as sustainability science has been rapidly developing [67]. Future sustainability measurement should consider combining the ecological footprint with EPI indicators.

\section{Paths to Sustainability}

\subsection{Development First}

Conventional thinking of environment-development relations regards income as the dominant explanation for variations in environmental success [64,68]. The notion of the Environmental Kuznets Curve (EKC) argues that the initial stages of economic growth are accompanied by increasing environmental degradation, once per capita income exceeds a given threshold, not only does the structure of the economy change, but people can also afford to demand a better environment $[69,70]$. There has been an intense debate on the applicability of the EKC. Numerous environmental and development economists cite a great deal of evidence to suggest that environmental degradation can be stopped and conditions can improve, as has happened in many areas of the world [71-73].

Some have regarded the EKC as the optimal growth path [74], in the belief that high income is a precondition for environmental recovery. Consequently they support the "grow first and clean up later" approach to development. That approach has attracted a great deal of attention in development and environmental policy $[69,71,75]$. According to my field experience in China in the past few years and Dasgupta et al., some policy makers have cited the EKC model when arguing that developing countries should "grow first and clean up later" [21,22,76], which means to develop the economy without paying attention to the environment until the country is wealthy enough.

On the other hand, Ezzati, Singer, and Kammen demonstrated that an EKC could only be obtained under specific circumstances among a multiplicity of possible outcomes [75]. Even then, it required attention to multiple factors that formed the economic-environmental system rather than a single dominant one. Borghesi and Vercelli point out that the optimistic implications of the EKC literature are not met and that the EKC is in principle unable to give reliable answers [77]. Raymon believed that the EKC idea is an inadequate guide for environmental policy makers around the globe [78]. Nahman and Antrobus pointed out that there is enough evidence to suggest that the EKC development path may not be available to today's developing countries [79].

Dasgupta et al. found that the atmospheric impact of fine particulate emissions on large cities worldwide does not support the view that air quality deteriorates during the first phase of economic growth [76]. They suggest that low levels of development should not prevent countries from having 
effective environmental institutions and policies. I argue that realizing an EKC is not the optimal growth path to sustainability, even if it may be applicable in certain cases [21]. Developing areas need to consider the environmental damage caused by the "grow first and clean up later" approach before moving to later stages of the EKC. Besides, environmental recovery at later stages of an EKC may not truly reflect an area's global environmental impact due to outsourcing pollution, which may not even be an option for developing areas. The EKC reflects only one of many nature-society relations and paths to sustainability. Developing areas should move beyond the EKC and take a sustainability approach at early stages of development.

In addition to income, a growing number of publications have put "good governance" as another factor in environmental success $[22,64,76,80,81]$. Ostrom shows that local communities often manage common resources - such as woods, lakes and fish stocks - better on their own than when outside authorities impose rules. "Bureaucrats sometimes do not have the correct information, while citizens and users of resources do" [82,83].

\subsection{Weak and Strong Sustainability}

There has also been a debate over weak and strong sustainability [84], regarding the relation between the environment and economy. Weak sustainability states that as long as the diminishing natural capital stocks are being replaced by gains in the man-made stock, total capital will stay constant and the current level of consumption can continue. The proponents believe that economic growth is beneficial as increased levels of income lead to increased levels of environmental protection. Conversely, strong sustainability theorists view natural capital and man-made capital as only complementary at best. They consider the Earth as finite and believe that no habitable future is possible unless the demand is radically reduced [85]. In order for sustainable development to be achieved, minimum amounts of a number of different types of capital (economic, ecological, social) should be independently maintained, in real physical/biological terms [86]. "Natural resources are essential inputs in economic production, consumption or welfare that cannot be substituted for by physical or human capital. Some environmental components are unique and some environmental processes may be irreversible [86]. Bahn and Gowdy argue that strong sustainability should be regarded as a goal or a process toward which the world strives rather than a formal framework from which we immediately implement global environmental policies [87].

\subsection{Sustainability Transition}

Environmental recovery is predicted to happen globally in certain scenarios of a transition towards sustainability [42,88-91]. According to Clark and Kates, the primary goals of a transition toward sustainability over the next two generations should be to meet the needs of a much larger but stabilizing human population, to sustain the life support systems of the planet, and to substantially reduce hunger and poverty, but if the current problems persist, many human needs will not be met, life support systems will be dangerously degraded, and the numbers of hungry and poor will increase. They believe that: 
A successful transition toward sustainability is possible over the next two generations. This transition could be achieved without miraculous technologies or drastic transformations of human societies. What will be required, however, are significant advances in basic knowledge, in the social capacity and technological capabilities to utilize it, and in the political will to turn this knowledge and know-how into action. Developing an integrated and place-based understanding of environmental threats and the options for dealing with them is a central challenge for promoting a transition toward sustainability [42].

Many other publications support the notion of sustainability transition [4,92-97].

\subsection{Sustainability Education}

The United Nations has recognized the central role of education in a global transition to sustainability. It declared a Decade of Education for Sustainable Development (ESD) (2005-2014) to integrate the principles, values, and practices of sustainable development into all aspects of education and learning to encourage changes in behavior that will create sustainability [98]. Numerous sustainability degree programs have been established around the world. For example, the American Association for Sustainability in Higher Education [99] has over 550 member colleges and universities, with 17 minor and 23 certificate programs, in addition to 16 Bachelor's, 13 Master's, and four PhD degree programs.

\section{Criticism of Sustainable Development}

The term of "sustainable development" has been criticized as being so vague that it can be applied to everything [24]. In some cases, there might an overuse of the term "sustainability." There is also much "green washing", the act of promoting a product or service as being environmentally friendly while it is not. On the other hand, I would argue that the term is not used enough as many disciplines that can contribute much to sustainability have not been actively involved.

Ehrenfeld gives emphasis to ethical dimension of sustainability (Figure 2a). He defines sustainability as the possibility that humans and other life will flourish on Earth forever [100]. He challenges conventional understandings of "solving" environmental problems as those possible remedies in the developed world, arguing that eco-efficiency, sustainable development, and corporate social responsibility may actually do more harm than good. To achieve sustainability, societies must focus on the "being" mode of human existence rather than on the unsustainable "having" mode we cling to now [100]. This notion of sustainability has been supported by other scholars as well [101,102]. Davison points out that a great deal has been written about the complexity and multiplicity of the concept of sustainability [103]. Finding the Venn diagrams unhelpful in his efforts to think through paradox in search of sustainability, he offers the metaphor of atomic structure as a potentially more interesting heuristic device to define sustainability (Figure 2b). He imagines principles of sustainability as a tightly aggregated nucleus around which orbit only loosely aggregated goals of sustainable development. "The small area of agreement established by the ideal of sustainability is nonetheless sufficient to bind together a wide constellation of diverse sustainable 
development objectives. These objectives orbit in varying relations of proximity and stability to sustainability ideals, establishing a large field of contestation [103]."

Figure 2. Diagrams illustrating definitions of sustainability as described by (a) Ehrenfeld and (b) Davison.
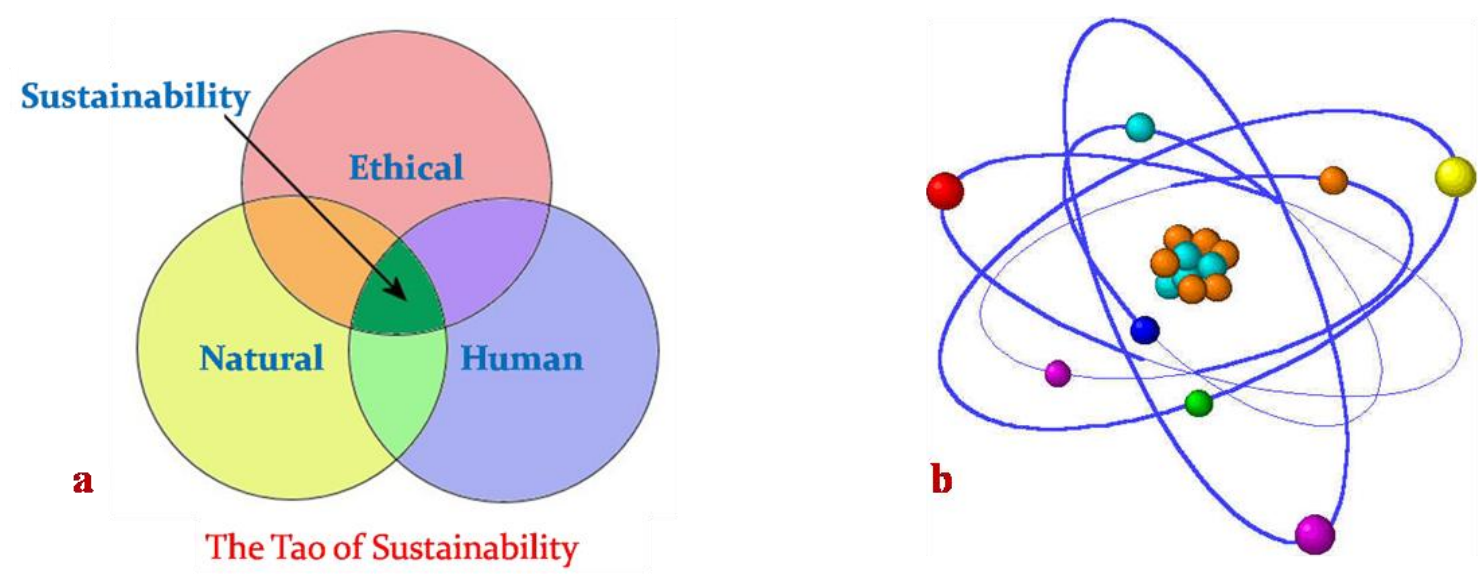

\section{Geographic Dimension of Sustainability}

Sustainability is studied and managed over many scales of space. The focus ranges from global to local: sustainability of planet Earth to the sustainability of countries, counties, municipalities, cities, villages, and neighborhoods, and from economic sectors to ecosystems. Geography has also been recognized as a factor affecting a place's environmental conditions [76] and sustainable city growth [104]. As the study of sustainability deepens, the newest approach to understanding the causes of sustainability has involved the rediscovery of geography and addresses physical and human geographic features because place matters [105]. There is an obvious lack of spatial analyses in the fast expanding sustainability literature. Are there spatial variations in sustainability performance? If there are, why do such variations exist? The sustainability of nations poses a geographic question that needs to be addressed: why are some places more sustainable than others? The geographic dimension of sustainability should be examined along with other dimensions, as some publications have done. Excellent examples on geographic perspectives to sustainable development are found in Leiserowitz, Kates and Paris [90] and Purvis and Grainger [106]. Zimmerer and Bassett [107] and Zimmerer [33,108] provide a thorough account of cultural ecology and political ecology approaches to environment-development studies. My earlier research find geography an important factor in understanding spatial variations in agricultural conservation [109], rural and urban income inequalities [110,111], nature reserve sustainability [112], and sustainability performance in China $[21,22,113]$. The following example using the Global Footprint information further illustrates how paying attention to the geographic dimension of sustainability can help us understand global sustainability issues.

The Global Footprint Network [66] states that:

As resource pressures escalate, ecological wealth will emerge as a growing geopolitical force, playing an increasingly important role in determining countries' competitiveness and 
its citizens' ability to lead secure, rewarding lives. Today, 80 percent of the world's population lives in countries that use more resources than what is renewably available within their own borders. These countries rely for their needs on resource surpluses concentrated in ecological creditor countries, which use less biocapacity than they have. As overshoot increases, growing ecological scarcity will increasingly influence and reshape our world map, from the 20th century distinction between "developing and developed" countries to one of Ecological Creditor and Debtor countries.

What we have just discussed above, including the definition and dimensions of sustainability and paths to sustainability, will be better understood when we examine the geography of the 2006 ecological creditor and debtor countries (Figure 3). A country's ranking is determined by the difference between its biocapacity and Ecological Footprint. Biocapacity refers to the capacity of ecosystems to produce useful biological materials and to absorb waste materials generated by humans, using current management schemes and extraction technologies. An ecological debtor country is one whose Footprint exceeds its biocapacity. Conversely, an ecological creditor is one whose biocapacity exceeds its Footprint. An ecological debtor country imports biocapacity through trade or liquidate its ecological assets.

Figure 3. Ecological debtor and creditor countries, 2006, comparing the ecological footprint of consumption with domestic biocapacity. Source: Global Footprint Network [66].

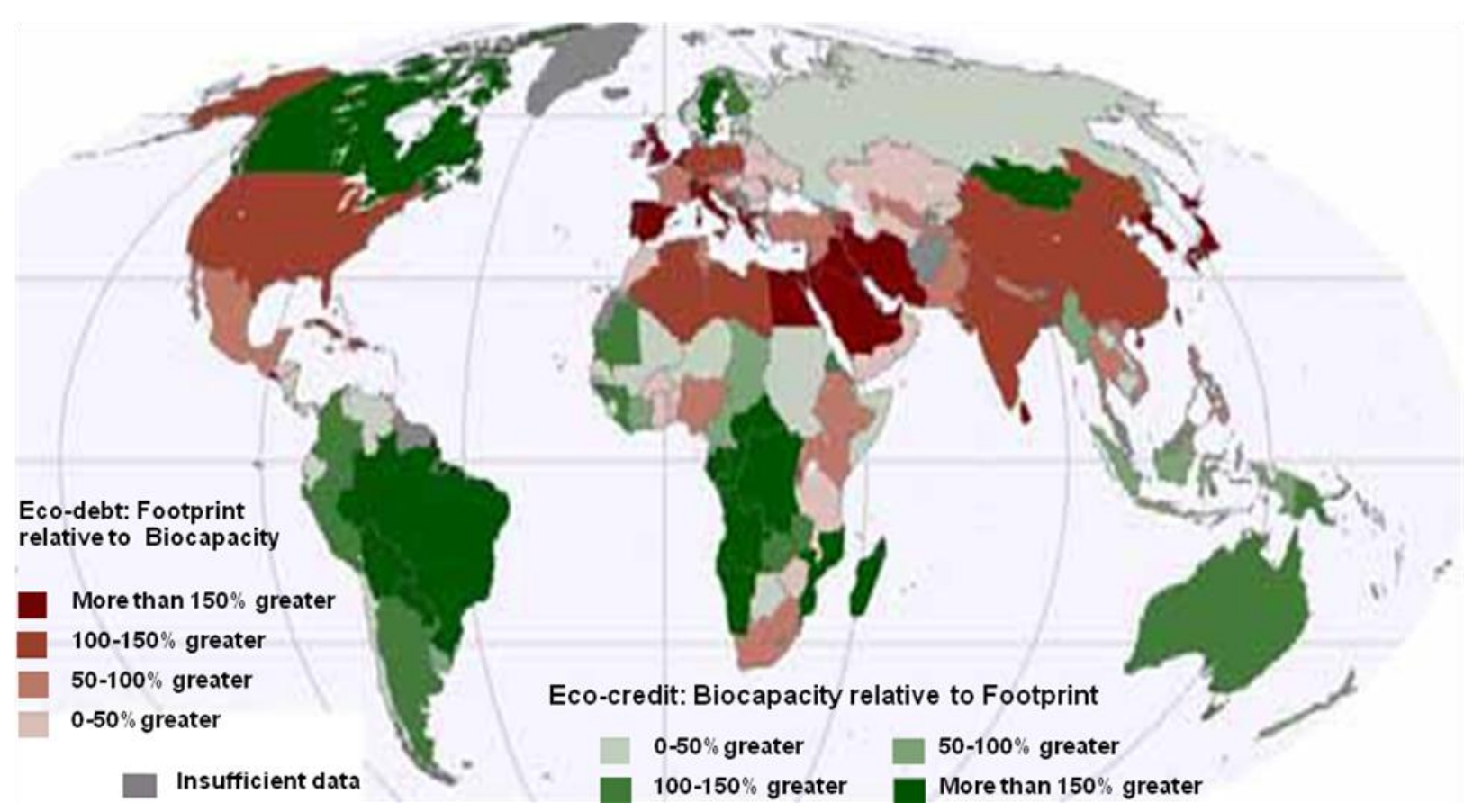

Figure 3 shows that nearly all the ecological debtor countries are located along the temperate and sub-tropical zone in the northern hemisphere, forming an ecological debtor belt. This belt contains most of the world's wealthier countries and the largest population concentrations. It is rich in minerals and resources such as coal, oil, and natural gas. Those wealthier countries are living beyond their ecological means [114]. They are meeting their present needs in an unsustainably way while 
compromising the ability of future generations to meet their needs. Through imports, they also compromise the ability of people in the poor countries to meet their needs.

On the other hand, the developing countries in this belt, such as China, India, Bangladesh, are not meeting their present needs while degrading their environment and compromising the ability of future generations to meet their needs. Individual Africans consume less on average than residents of any other continent, but rising population is bringing Africa close to its ecological limits, according to a new report prepared for the World Wildlife Fund (WWF) by the Global Footprint Network [115]. What does sustainability mean to the people who cannot meet their needs but are compromising the ability of future generations to meet their needs? Transition to sustainability is possible for people in the wealthier countries by reducing consumption. Transition to sustainability will be even more challenging, if not impossible, for people in poor countries which cannot meet their needs but have been degrading their environment rapidly.

Rosen states that issues like continuing population growth and rapidly rising affluence in many parts of the world [8], which increase the demand for energy resources, also must be addressed given the significant implications they have on the sustainability of energy systems. Clark and Kates point out that most of the future population growth will be concentrated in the developing countries [42], where the need to reduce poverty without harming the environment will be particularly acute, and meeting even the most basic needs in the developing world implies greater production and consumption of goods and services, increased demand for land, energy, and materials, and intensified pressures on the environment and living resources.

Transition to sustainability requires reducing human consumption to within ecological limits. Every place and every person is a part of global sustainability because it takes every place and every person, the whole global village, to achieve sustainability. That involves cultural changes. The more developed world and the wealthy in the developing world must take the lead in this cultural change. The current popular culture underlying individualistic and materialistic values is one of the causes of unsustainability. Clark and Kates believe that a priority for sustainability research is to develop a research framework that integrates global and local perspectives to shape a "place-based" understanding of the interactions between environment and society [42].

The current definitions of sustainability do not adequately address the dilemma many developing countries face that neither needs of the present or the future can be met, as their resources are so limited by geography and needs are defined differently. I would like to attempt to address the dilemma by proposing that the goal of sustainability be defined as "living within one's own ecological means." "Living" refers to meeting basic human needs for life, but not everything one needs (or wants). This definition specifies "one's own ecological means" which is determined by one's own carrying capacity locally or regionally and indicates a geographic dimension. "One" may be an individual, a community, a county, a region, a country, or the whole world, that is responsible for living within one's own means.

What constitutes exactly as "one's own" is a reflection of social, cultural and economic factors and open to interpretation. Urban areas will have to rely on surrounding hinterland for living. Wealthy areas will import materials from poorer areas. However, this definition urges the places that are living beyond their ecological means to reduce consumption as fast and as much as they can manage. People in the developing countries need to realize that the life style of their wealthy and the more developed countries is environmentally unsustainable. Development at the expense of the environment is not the 
optimal approach. They must live or develop within their own ecological means which varies greatly across the world.

\section{Conclusions}

This paper raises questions about the definitions of sustainability through a review of the sustainability concept, dimensions, indicators, and approaches for achieving sustainability. One question is that the definitions tend to assume that the Earth is able to provide enough resources for humankind to meet both present and future needs. That assumption encourages economic development in the hope that it will eventually lead to better life for all. However, it is difficult to verify that assumption for all regions of the world. Besides, it is difficult to define "needs." It is likely that needs for all people may never be met due to ecological capacity and economic disparity. There are also many different dimensions of sustainability, which enhance understanding of the sustainability concept. However, as the number of dimensions increases, the scope of sustainability also increases, as if humankind can solve all problems, economic, social, political, and ethical, with sustainability. And people's "needs" keep increasing. It may be better we cool down a little and define sustainability as something that would be less ideal. We still do not have accepted indicators of sustainability, though ecological Footprint analysis is gaining popularity. It is important we know how much we have as our ecological means, locally, regionally, and globally. Before that, it is better to be conservative about how much we have and accept the limits to growth by trying to "live within one's own ecological means." The "grow first and clean up later" approach to development is unsustainable and may no longer be available. The paper proposes that the goal of sustainability be defined as "living within one's own ecological means" which invites further debates and research on sustainability. It will be very important for the sustainability science to meet all the challenges ahead so that transition to sustainability may be possible.

\section{Acknowledgements}

This research was funded by two University Research Program Grants, five Professional Development Assistance Grants, and Three College Research and Creative Assistance Awards from the University of Central Missouri in 2002-2008. The paper benefited from discussions in my classes: Introduction to Sustainability and Conservation of Natural Resources. Part of the paper was presented as University of Central Missouri Honors College Inaugurational Faculty Fellow Lecture. I am especially grateful to the Sustainability editors, the anonymous reviewers, and my students for their thoughtful comments on an earlier version of the paper.

\section{References and Notes}

1. Intergovernmental Panel on Climate Change (IPCC). Climate Change: Mitigation; Contribution of Working Group III to the Fourth Assessment Report of the Intergovernmental Panel on Climate Change; Metz, B., Davidson, O.R., Bosch, P.R., Dave, R., Meyer, L.A., Eds.; Cambridge University Press: Cambridge, UK, 2007. 
2. Clark, W.; Dickson, N. Sustainability science: the emerging research program. Proc. Natl. Acad. Sci. USA 2003, 100, 8059-8061.

3. Kates, R.W.; Parris, T.M. Long-term trends and a sustainability transition. Proc. Natl. Acad. Sci. USA 2003, 100, 8062-8067.

4. Parris, T.M.; Kates, R.W. Characterizing a sustainability transition: goals, targets, trends, and driving forces. Proc. Natl. Acad. Sci. USA 2003, 100, 8068-8073.

5. Turner II, B.L.; Kasperson, R.; Matson, P.; McCarthy, J.; Corell, R.; Christensen, L.; Eckley, N.; Kasperson, J.X.; Luers, A.; Martello, M.; Polsky, C.; Pulsipher, A.; Schiller, A. A framework for vulnerability analysis in sustainability science. Proc. Natl. Acad. Sci. USA 2003, 100, 8074-8079

6. Clark, W. Sustainability science: a room of its own. Proc. Natl. Acad. Sci. USA 2007, 104, 1737-1738.

7. Curran, M.A. Wrapping our brains around sustainability. Sustainability 2009, 1, 5-13.

8. Rosen, M.A. Sustainability: a crucial quest for humanity - welcome to a new open access journal for a growing multidisciplinary community. Sustainability 2009, 1, 1-4.

9. Stocking, M. Measuring land degradation. In Land Degradation and Society; Blaikie, P.M., Brookfield, H.C., Eds.; Methuen \& Co.: London, UK, 1987; pp. 49-63.

10. Adams, W.M. Green Development: Environment and Sustainability in the Third World; Routledge: London, UK, 1990.

11. Redclift, M. Sustainable development: needs, values, rights. Environ. Value 1993, 2, 3-20.

12. Torgerson, D. Strategy and ideology in environmentalism: a decentralized approach to sustainability. Ind. Environ. Crisis Quart. 1994, 8, 295-321.

13. Brady, G.L.; Geets, P.C. Sustainable development: the challenge of implementation. Int. J. Sustain. Dev. World Ecol. 1994, 1, 189-197.

14. Karshenas, M. Environment, technology and employment: towards a new definition of Sustainable Development. Dev. Change 1994, 25, 723-56.

15. Defining and Measuring Sustainability: The Biological Foundations; Munasinghe, M., Shearer, W., Eds.; World Bank: Washington, DC, USA. 1995.

16. A Sustainable World: Defining and Measuring Sustainable Development; Trzyna, T.C., Osborn, J.K., Eds.; California Institute of Public Affairs: Sacramento, CA, USA, 1995.

17. Cruz, W.; Munasinghe, M.; Warford, J. Greening development: environmental implications of economic policies. Environment 1996, 38, 6-11, 31-38.

18. Pretty, J.; Hine, R. The promising spread of sustainable agriculture in Asia. Nat. Resour. Forum 2000, 24, 107-121.

19. Farrell, A.; Hart, M. What does sustainability really mean? The search for useful indicators. Environment 1998, 40, 4-15.

20. Zhang, R.; Zhang, H.; Zhang, R. Environmental Protection and Sustainable Agricultural Development in China; Beijing Publishing House: Beijing, China, 2001.

21. Liu, L. Sustainability efforts in China: reflections on the Environmental Kuznets Curve through a locational evaluation of "Eco-Communities". Ann. Assoc. Am. Geogr. 2008, 98, 604-629.

22. Liu, L. Urban environmental performance in China: a sustainability divide? Sustain. Dev. 2009, $17,1-18$. 
23. World Commission on Environment and Development (WCED). Our Common Future; Oxford University Press: New York, NY, USA, 1987.

24. Barrett, G.W.; Odum, E.P. The twenty-first century: the world at carrying capacity. Bioscience 2000, 50, 363-368.

25. Conway, G. Agro-ecosystem analysis. Agr. Admin. 1985, 20, 31-55.

26. Agricultural Sustainability: Economic, Environmental and Statistical Considerations; Barnett, V., Payne, R., Steiner, R., Eds.; John Wiley \& Sons: New York, NY, USA, 1995.

27. Tisdell, C. Sustainable development: differing perspectives of ecologists and economists, and relevance to LDCs. World Dev. 1988, 6, 373-84.

28. Losada, H.; Vieyra, J.; Soriano, R.; Bennett, R.; Cortes, J. Assessing the sustainability of a terraced agroecosystem for production of maple vegetable in metropolitan Mexico City. Am. J. Altern. Agr. 2001, 16, 98-105.

29. Altieri, M. Agro-Ecology: The Scientific Basis for Alternative Agriculture; IT Publications: London, UK, 1987.

30. Shi, Y.; Wang, J. Theory and research in sustainable agriculture. J. Jilin Agr. Sci. 1998, 23, 83-87.

31. O'Connor, J. Natural Causes: Essays in Ecological Marxism; Guilford: London, UK, 1998.

32. Sanders, R. Political economy of Chinese ecological agriculture: a case study of seven Chinese eco-villages. J. Contemp. China 2000, 9, 349-372.

33. Zimmerer, K.S. The reworking of conservation geographies: nonequilibrium landscapes and nature-society hybrids. Ann. Assoc. Am. Geogr. 2000, 90, 356-69.

34. Rosen, M.A. energy sustainability: a pragmatic approach and illustrations. Sustainability 2009, 1, 55-80.

35. Caviglia, J.L. Sustainable Agriculture in Brazil; Edward Elgar: Cheltenham, UK, 1999.

36. Shi, T. Operationalizing sustainability: an emerging eco-philosophy in Chinese ecological agriculture. J. Sustain. Agri. 2004, 24, 113-131. Available online: http://202.114.224.27/rkzyhj/ zyyjfxdt/stjj/200605/P020060513009353277376.pdf/ (accessed on 22 October 2009).

37. Ma, S. Application of economic ecology principles to industrial and agricultural construction. Ecol. Sinica. 1983, 3, 1-6.

38. Li, W.; Min, Q. Integrated farming systems: an important approach toward sustainable agriculture in China. Ambio 1999, 28, 655-62.

39. Construction of an Ecological Province in Jilin; Jilin Province Environmental Protection Administration (JPEPA): Jilin, China, 2002.

40. Hoag, D.L.; Skold, M.D. The relationship between conservation and sustainability. J. Soil Water Conserv. 1996, 51, 292-295.

41. Humanity Now Demanding 1.4 Earths; Global Footprint Network: Oakland, CA, USA, 2009; Available online: http://www.footprintnetwork.org/en/index.php/GFN/blog/ (accessed on 10 December 2009).

42. Sustainable Development an Evolving Concept; United Nations Educational, Scientific and Cultural Organization (UNESCO): Paris, France, 2004; Available online: http://portal.unesco.org/education/en/files/30363/11035294683brief_Concept_of_ESD.pdf/brief+ Concept+of+ESD.pdf/ (accessed on 4 December 2009). 
43. Board on Sustainable Development, National Research Council. Our Common Journey: A Transition toward Sustainability; National Academy Press: Washington, DC, USA, 1999.

44. Press Conference on National Day Military Parade, 24 September 2009; Available online: http://live.people.com.cn/note.phpid=775090923101734_ctdzb_001/ (accessed on 10 December 2009).

45. 2005 World Summit Outcome, Resolution A/60/1, Adopted by the General Assembly on 15 September 2005; United Nations General Assembly: New York, NY, USA, 2005; Available at: http://daccessdds.un.org/doc/UNDOC/GEN/N05/487/60/PDF/N0548760.pdfOpenElement/ (accessed on 1 December 2009).

46. Adams, W.M. The future of sustainability: re-thinking environment and development in the twenty-first century. In Proceedings of the IUCN Renowned Thinkers Meeting, Gland, Switzerland, January 29-31, 2006.

47. Porritt, J. Capitalism as if the World Mattered; Earthscan: London, UK, 2006; p. 46.

48. Ott, K. The case for strong sustainability. In Greifswald's Environmental Ethics; Ott, K., Thapa, P., Eds.; Steinbecker Verlag Ulrich Rose: Greifswald, Germany, 2003.

49. Daly, H.; Cobb, J. For the Common Good: Redirecting the Economy toward Community, the Environment and a Sustainable Future; Beacon Press: Boston, MA, USA, 1989.

50. Universal Declaration on Cultural Diversity; United Nations Educational, Scientific and Cultural Organization (UNESCO): Paris, France; 2001; Available online: http://unesdoc.unesco.org/ images/0012/001271/127160m.pdf/ (accessed on 10 December 2009).

51. Culture and Sustainability; University of New Hampshire: Durham, NH, USA, 2009; Available online: http://www.sustainableunh.unh.edu/culture_sust/whyculture.html (accessed on 10 December 2009).

52. Master of arts in cultural sustainability; Available online: http://www.goucher.edu/x31960.xml/ (accessed on 10 December 2009).

53. Common ground, environmental, cultural, economic and social sustainability; Available online: http://onsustainability.com/ (accessed on 10 December 2009).

54. Pawlowski, A. How many dimensions does sustainable development have? Sustain. Dev. 2008, 16, 81-90.

55. Piatek, Z. Ecophilosophy as a philosophical underpinning of sustainable development. Sustain. Dev. 2008, 16, 91-99.

56. Tyburski, W. Origin and development of ecological philosophy and environmental ethics and their impact of the idea of sustainable development. Sustain. Dev. 2008, 16, 100-108.

57. Papuzinski, A. The philosophical dimension to the principle of sustainable development in the Polish scientific literature. Sustain. Dev. 2008, 16, 117-125.

58. Skowroński, A. A civilization based on sustainable development: its limits and prospects. Sustain. Dev. 2008, 16, 117-125.

59. Pataki, G. Ecological modernization as paradigm of corporate sustainability. Sustain. Dev. 2009, 17, 83-91.

60. Wen, J.B. Full Implementation of the Scientific Concept of Development to Speed up the Building of an Environment-Friendly Society; 2006; Available online: http://news.xinhuanet.com/ newscenter/2006-04/23/content_4463242.htm/ (accessed on 10 December 2009). 
61. Zhou, S. Promote national ecological safety and human-nature harmony. In Proceedings of the 50th Anniversary of Nature Reserve Program, Beijing, China, 27 October 2006; Available online: http://www.zhb.gov.cn/xcjy/zwhb/200610/t20061027_95187.htm/ (accessed on 10 December 2009).

62. Kates, R.; Clark, W.; Corell, R.; Hall, J.; Jaeger, C.; Lowe, I.; McCarthy, J.; Schellnhuber, H.; Bolin, B.; Dickson, N.; Faucheux, S.; Gallopin, G.; Grubler, A.; Huntley, B.; Jager, J.; Jodha, N.; Kasperson, R.; Mabogunje, A.; Matson, P.; Mooney, H. Sustainability science. Science, 2001, 292, 641-642.

63. Sustainability Science Program; Center for International Development, Harvard University: Cambridge, MA, USA; Available online: http://www.hks.harvard.edu/centers/cid/programs/ sustsci/ (accessed on 10 December 2009).

64. Esty, D.C.; Levy, M.A.; Kim, C.H.; de Sherbinin, A.; Srebotnjak, T.; Mara, V. 2008 Environmental Performance Index; Yale Center for Environmental Law and Policy: New Haven, CT, USA, 2008; Available online: http://epi.yale.edu/ (accessed on 10 December 2009).

65. Liu, L. How green is the 2008 Global Environmental Performance Index? Unpublished manuscript.

66. Ecological Creditors and Debtors; Global Footprint Network: Oakland, CA, USA, 2006; Available online: http://www.footprintnetwork.org/en/index.php/GFN/page/ecological_debtors_ and_creditors/ (accessed on 10 December 2009).

67. Holden, E.; Linnerud, K. The Sustain Dev area: satisfying basic needs and safeguarding ecological sustainability. Sustain. Dev. 2007, 15, 174-187.

68. How Green Is Their Growth; The Economist: Los Angeles, CA, USA, 2008; Available online: http://www.economist.com/world/international/displaystory.cfm?story_id=10566738/ (accessed on 10 December 2009).

69. Beckerman, W. Economic growth and the environment. World Dev. 1992, 20, 481-496.

70. Shafik, N. Economic development and environmental quality: an econometric analysis. Oxford Econ. Pap. 1994, 46, 757-773.

71. World Bank. World Development Report 1992: Development and Environment; Oxford University Press: New York, NY, USA, 1992.

72. Scherr, S.J.; Yadav, S. Land Degradation in Developing World: Implications for Food, Agriculture, and the Environment to 2020; Food, Agriculture, and Environment Discussion Paper No. 14; International Food Policy Research Institute: Washington, DC, USA. 1996.

73. Johansson, P. Stairway to sustainability. Earthwatch 1998, 18, 28-37.

74. Chimeli, A.B.; Braden, J.B. The Environmental Kuznets Curve and Optimal Growth; The International Research Institute for Climate and Society: Palisades, NY, USA, 2002; Available online: http://iri.columbia.edu/ chimeli/wpps/envdynpost.pdf/ (accessed on 10 December 2009).

75. Ezzati, M.; Singer, B.H.; Kammen, D.M. Towards an integrated framework for development and environment policy: The dynamics of Environmental Kuznets Curves. World Dev. 2001, 29, 1421-1434.

76. Dasgupta, S.; Hamilton, K.; Pandey, K.D.; Wheeler, D. Environment during growth: accounting for governance and vulnerability. World Dev. 2006, 34, 1597-1611.

77. Borghesi, S.; Vercelli, A. Sustainable globalisation. Ecol. Econ. 2003, 44, 77-89. 
78. Raymond, L. Economic growth as environmental policy? Reconsidering the Environmental Kuznets Curve. J. Public Policy 2004, 24, 327-348.

79. Nahman, A.; Antrobus, G. The Environmental Kuznets Curve: a literature survey. S. Afr. J. Econ. 2005, 73, 105-120.

80. Mol, A.P.; Carter, N. China's environmental governance in transition. In Environmental Governance in China; Carter, N., Mol, A.P., Eds.; Routledge: London, UK, 2007; pp. 1-22.

81. Tao, J.; Mah, D.N. Between market and state: dilemmas of environmental governance in China's sulphur dioxide emission trading system. Environ. Plan. C: Gov. Policy. 2009, 27, 175-188.

82. Ostrom, E. Governing the Commons: The Evolution of Institutions for Collective Action; Cambridge University Press: New York, NY, USA, 1990.

83. First woman wins Nobel Prize for Economics. CNN, 12 October 2009; Available online: http://www.cnn.com/2009/WORLD/europe/10/12/nobel.economics/index.html. (accessed on 10 December 2009)

84. Dietza, S.; Neumayer, E. Weak and strong sustainability in the SEEA: concepts and measurement. Ecol. Econ. 2007, 61, 617-626.

85. Williams, C.C.; Millington, A.C. The diverse and contested meanings of sustainable development. Geogr. J. 2004, 170, 99-104.

86. Brekke, K.A. Economic Growth and the Environment: On the Measurement of Income and Welfare; Edward Elgar: Cheltenham, UK, 1997.

87. Bahn, A.; Gowdy, J. Economics weak and strong: ecological economics and human survival. World Future. 2003, 59, 253-262.

88. Ruttan, V.W. The transition to agricultural sustainability. Proc. Natl. Acad. Sci. USA 1999, 96, 5960-5967.

89. Aldy, J.E. An Environmental Kuznets Curve analysis of U.S. state-level carbon dioxide emissions. J. Environ. Dev. 2005, 14, 48-71.

90. Leiserowitz, A.A.; Kates, R.W.; Paris, T.M. Sustainability values, attitudes, and behaviors: a review of multinational and global trends. Annu. Rev. Env. Resour. 2006, 31, 413-444.

91. Kates, R.W; Parris, T. Geography, environment, sustainability, culture and education. In Environmental and Geographic Education for Sustainability: Cultural Contexts; Kates, R.W., Parris, T., Eds.; Nova Science Publishers: New York, NY, USA, 2006; pp. 3-22.

92. Lee, K.N. Searching for sustainability in the new century. Ecol. Law Quart. 2001, 27, 913-929.

93. Kates, R.W. Population and consumption: what we know, what we need to know. Environment 2000, 42, 10-19.

94. Daily, G.C.; Walker, B.H. Seeking the great transition: environmentally sustainable economies are unachievable without enhanced participation of the private sector. Scientists must facilitate this process. Nature 2000, 403, 243-245.

95. Clark, W.C. Research systems for a transition toward sustainability. In Challenges of a Changing Earth, Proceedings of the Global Change Open Science Conference, Amsterdam, The Netherlands, 10-13 July 2001; Steffen, W., Jäger, J., Carson, D., Bradshaw, C., Eds.; Springer-Verlag: Berlin, Germany, 2002; pp. 197-200.

96. O'Riordan, T.; Voisey, H. The Transition to Sustainability: The Politics of Agenda 21 in Europe; Earthscan Publications: London, UK, 1998. 
97. Pretty, J. The sustainable intensification of agriculture. Nat. Resour. Forum 1997, 21, 247-256.

98. Education for Sustainable Development; United Nations Educational, Scientific and Cultural Organization (UNESCO): Paris, France, 2008; Available online: http://portal.unesco.org/ education/en/ev.php-url_id=27234\&url_do=do_topic\&url_section=201.html (accessed on 10 December 2009).

99. American Association for Sustainability in Higher Education (AASHE). http://www.aashe.org (accessed on 10 December 2009).

100. Ehrenfeld, J. Sustainability by Design: A Subversive Strategy for Transforming Our Consumer Culture; Yale University Press: New Haven, CT, USA, 2008; pp. 143-145.

101. Hubson, K. Consumption, environmental sustainability and human geography in Australia: a missing research agenda? Aust. Geogr. Stud. 2003, 41, 148-155.

102. Goerner, S; Dyck, R; Lagerroos, D. The New Science of Sustainability, Building a Foundation for Great Change; New Society: Gabriola Island, BC, Canada, 2008.

103. Davison, A. Contesting sustainability in theory-practice: in praise of ambivalence. J. Media Cult. Stud. 2008, 22, 191-199.

104. Ding, C. Policy and planning challenges to promote efficient urban spatial development during the emerging rapid transformation in China. Sustainability 2009, 1, 384-408.

105. Kates, R.W.; Dasgupta, P. African poverty: a grand challenge for sustainability science. Proc. Natl. Acad. Sci. USA 2007, 104, 16747-16750.

106. Exploring Sustainable Development: Geographical Perspectives; Purvis, M., Grainger, A., Eds.; Earthscan: London, UK. 2004.

107. Zimmerer, K.S.; Bassett, T.J. Political Ecology: An Integrative Approach to Geography and Environment-Development Studies; Guilford: New York, NY, USA, 2003.

108. Zimmerer, K.S. Cultural ecology: at the interface with political ecology: the new geographies of environmental conservation and globalization. Prog. Hum. Geog. 2006, 30, 63-78.

109. Liu, L. Labor location, conservation, and land quality: the case of west Jilin, China. Ann. Assoc. Am. Geogr. 1999, 89, 633-657.

110. Liu, L. Impacts of market location on rural poverty and income inequality in China. Chin. Econ. 2006, 39, 64-78.

111. Liu, L. National market location and spatial variation in urban-rural inequality in China. Int. Dev. Plann. Rev. 2009, 31, 381-406.

112. Zhang, Z.; Liu, L.; Li, X. Ecotourism and nature reserve sustainability in environmentally fragile poor areas: the case of the ordos relict gull reserve in China. Sustain. Sci. Pract. Policy 2009, 4 , 12-22.

113. Liu, L. A regional divide in sustainability performance in China: Geography, governance, and income. Sustain. Deve 2009, 17, doi: 10.1002/sd.432; Available online: www.interscience. wiley.com/ (accessed on 16 September 2009).

114. EU economies living beyond ecological means. Environmental News Network, 19 November 2007; Available online: http://www.enn.com/business/article/25397 (accessed on 10 December 2009). 
115. Modest African footprint still approaching limits. Environmental News Network, 9 June 2008; Available online: http://www.enn.com/top_stories/article/37336 (accessed on 10 December 2009).

(C) 2009 by the authors; licensee Molecular Diversity Preservation International, Basel, Switzerland. This article is an open-access article distributed under the terms and conditions of the Creative Commons Attribution license (http://creativecommons.org/licenses/by/3.0/). 